\title{
Peningkatan Karakter Gotong Royong di Sekolah Dasar
}

\author{
Desti Mulyani $^{1]}$, Syamsul Ghufron ${ }^{2]}$, Akhwani ${ }^{3]}$, Suharmono Kasiyun ${ }^{4]}$ \\ Universitas Nahdlatul Ulama Surabaya \\ E-mail: ${ }^{1]}$ desti.mul98@gmail.com \\ ${ }^{2]}$ syamsulghufron@unusa.ac.id \\ 3] akhwani@unusa.ac.id \\ ${ }^{4]}$ Harmono_ka@yahoo.com
}

\begin{abstract}
Abstrak
Gotong royong merupakan suatu bentuk kerja sama baik itu individu, individu dengan kelompok untuk melakukan kerja sama dalam menangani permasalahan yang menjadi kepentingan bersama. sesuai dengan tujuan permendikbud gotong royong merupakan salah satu upaya peningkatan pendidikan karakter di sekolah. Tujuan penelitian ini adalah mendeskripsikan bentuk-bentuk perilaku gotong royong yang masih bertahan, mendeskripsikan strategi guru dalam penanaman dan peningkatan karakter gotong royong siswa, mendeskripsikan tema/topik pembelajaran yang menjadi sarana penanaman dan peningkatan karakter gotong royong siswa di SDN Jemur Wonosari 1/417 Surabaya. Metode penelitian ini adalah pendekatan kualitatif yang bersifat deskriptif. Subjek penelitian ini yaitu guru kelas 3a, 3b, 4b, 5b, 6a, 6b. Pengumpulan data pada penelitin ini dilakukan dengan teknik observasi dan wawancara. Teknik analisis data menggunakan reduksi data, display data, dan verifikasi data. Hasil yang diperoleh menunjukkan bahwa program pendidikan berbasis gotong royong masih bertahan hingga sekarang, namun ada beberapa siswa saja yang sulit dalam melakukan sikap gotong royong dan masih dikategorikan baik. Adapun strategi guru dalam menanamkan sikap karakter gotong royong seperti memberi contoh langsung kepada siswa, memberikan reward berupa pujian-pujian sehingga semangat gotong royong siswa sejalan dengan tujuan pendidikan di sekolah. Dalam penerapan sikap gotong royong guru menggunakan beberapa substansi dalam pembelajaran seperti pembelajaran PKn, IPS, Matematika, Bahasa Indonesia, SBdP.
\end{abstract}

Kata Kunci: Peningkatan, Karakter, Gotong Royong

\section{Enhancing the character of mutual cooperation in Elementay School}

\begin{abstract}
Mutual cooperation is a form of good cooperation that individuals, individuals and group to cooperate in agreements that are of common interest. In accordance with the goals of mutual cooperation permendikbud is one of the effort to inprove character education in schools. The purpose of this study is to describe the form of study of mutual cooperation that still survive, describe the teacher's strategy in planning and improving the character of student cooperation, desribing the theme/ topic of learning as a means of developing and inproving the character of mutual cooperation in SDN Jemur Wonosari 1/417 Surabaya. The subjects of this study were class $3 a, 3 b, 4 b, 5 b$, $6 a, 6 b$ teachers. The meeting of the data in this study was conducted by observation
\end{abstract}


and interview techniques. Data analysis techniques use data reduction, display data, and verify data. The result obtained from the mutual cooperation based education program still persist until now, but there are only a few students who find it difficult to do mutual cooperation and are still categorized well. As for the teacher's strategy in instilling the attitude of mutual cooperaion characters such as giving examples directly to students, giving gifts in the form of appreciation with the spirit of mutual cooperation of students in accordance with the education goals at school. In the application of mutual cooperation teacher uses several substances in learning such as PKn, IPS, Mathematics, Indonesian, SBdP.

Keywords: Enhancement, Character, Mutual Cooperation

\section{PENDAHULUAN}

Kemajuan suatu bangsa tergantung dari kualitas Sumber Daya Manusia (SDM) bangsa tersebut. SDM yang berkualitas menjadi salah satu modal utama dalam kemajuan suatu bangsa baik dalam bidang ekonomi, IPTEK, politik, budaya, maupun karakter bangsa. Untuk mengembangkan SDM tersebut salah satunya melalui dunia pendidikan yang berkualitas pula.

Dunia pendidikan dapat dijadikan tumpuan kemajuan bangsa Indonesia. Sebagaimana bangsa-bangsa Jepang, Jerman bahkan yang dekat dengan Indonesia yaitu Malaysia juga menguntungkan kemajuan bangsanya melalui penyelenggaraan pendidikan yang berkualitas, termasuk Indonesia tidak pernah surut melakukan upaya meningkatkan mutu pendidikan (Nunzairina, 2018).

Salah satu upaya peningkatan mutu pendidikan itu adalah penguatan karakter bangsa. Penguatan karakter bangsa menjadi salah satu butir Nawacita yang dicanangkan Presiden Joko Widodo melalui Gerakan Nasional Revolusi Mental (GNRM). Komitmen ini ditindaklanjuti dengan arahan Presiden kepada Menteri Pendidikan dan Kebudayaan untuk mengutamakan dan membudayakan pendidikan karakter di dalam dunia pendidikan. Atas dasar ini,
Kementerian Pendidikan dan Kebudayaan mencanangkan Penguatan Pendidikan Karakter (PPK) secara bertahap mulai tahun 2016.

Penguatan Pendidikan Karakter bukanlah suatu kebijakan baru sama sekali karena sejak tahun 2010 pendidikan karakter di sekolah sudah menjadi Gerakan Nasional. Satuan pendidikan menjadi sarana strategis bagi pembentukan karakter bangsa karena memiliki sistem, infrastruktur, dan dukungan ekosistem pendidikan yang tersebar di seluruh Indonesia, mulai dari perkotaan sampai pedesaan. Sudah banyak pendidikan karakter baik yang dikembangkan sekolah, namun masih banyak pekerjaan rumah yang harus dituntaskan untuk memastikan agar proses pembudayaan nilai-nilai karakter berjalan dan berkesinambungan. Selain itu, sangat diperlukan kebijakan yang lebih komprehensif dan bertumpu pada kearifan lokal untuk menjawab tantangan zaman yang makin kompleks, mulai dari persoalan yang mengancam keutuhan dan masa depan bangsa sampai kepada persaingan global. Kebijakan ini akan menjadi dasar bagi perumusan langkah-langkah yang lebih konkret agar penyemaian dan pembudayaan nilai-nilai utama pembentukan karakter bangsa dapat dilakukan secara efektif dan menyeluruh baik di lingkungan 
masyaraat maupun di sekolah dasar (Kemendikbud, 2017).

Permendikbud No. 20 Tahun 2018 Pasal 2 ayat 1 menyatakan bahwa PPK dilaksanakan dengan menerapkan nilai-nilai Pancasila dalam pendidikan karakter terutama meliputi nilai-nilai religius, jujur, toleran, disiplin, bekerja keras, kreatif, mandiri, demokratis, rasa ingin tahu, semangat kebangsaan, cinta tanah air, menghargai prestasi, komunikatif, cinta damai, gemar membaca, peduli lingkungan, peduli sosial, dan bertanggung jawab.

Permendikbud No. 20 Tahun 2018 Pasal 2 ayat 2 nilai sebagaimana dimaksud pada ayat (1) merupakan perwujudan dari 5 (lima) nilai utama yang saling berkaitan yaitu religiusitas, nasionalisme, kemandirian, gotong royong, dan integritas yang terintegrasi dalam kurikulum.

Dalam Penguatan Pendidikan Karakter terdapat lima prinsip yakni nasionalisme, integritas, kemandirian, gotong royong, dan religius. Dari paparan di atas, terlihat bahwa karakter gotong royong merupakan salah satu karakter yang berusaha dikuatkan oleh pemerintah melalui Pendidikan formal termasuk sekolah dasar.

Tujuan program penguatan pendidikan karakter gotong royong sendiri adalah untuk menanamkan pembentukan nilai-nilai karakter bangsa kepeserta didik efektif melalui lembaga pendidikan dengan prioritas nilai-nilai tertentu yang akan menjadikan proses pembelajaran, pemahaman, pengertian dan praktik, sehingga pendidikan karakter gotong royong mampu mengubah perilaku, cara berfikir, dan cara bertindak, seluruh bangsa Indonesia menjadi lebih baik dan berintegritas (Khotimah N. D., 2019).

Akan tetapi, hasil pengamatan peneliti di SDN Jemur Wonosari 1
Surabaya menunjukkan bahwa perilaku gotong royong siswa sedikit memudar. Semangat kerja sama di antara siswa di sekolah menurun. Mereka tidak lagi bahu-membahu dalam menyelesaikan persoalan bersama. Mereka kurang menjalin komunikasi.

Fenomena ini sejalan dengan hasil pengamatan Djamari (2016) menyatakan di SDN 3 Kronggen Grobogan masih kurang sekali keinginan siswa untuk ikut serta atau berperan dalam mengadakan gorong royong baik itu dalam menjaga kebersihan lingkungan sekolah maupun dalam hal pembangunan sekolah dan lain-lain. Padahal sekolah sering mengadakan kegiatan gotong royong seperti membersihkan lingkungan sekolah, bergotong royong dalam mempersiapkan perlengkapan acaraacara yang ada disekolah, dan sebagainya. Namun hanya sedikit siswa yang mau ikut bekerja sama dalam kegiatan bergotong royong dan juga tidak sedikit siswa yang menganggap kegiatan gotong royong itu adalah hal yang kampungan dan sepele.

Aviani, (2020) juga menyimpulkan bahwa di daerah pedesaan masih banyak dijumpai orang bergotong royong, sedangkan di kota besar sudah sangat jarang bahkan hampir tidak ada gotong royong. Hanafi (2016) menambahkan penjelasan bahwa perilaku budaya gotong royong sikap hidup bangsa telah mengalami perubahan dan hanya mementingkan kebebasan individu.

Hasil angket yang disebarkan Setiawan (2016), bahwa siswa kelas 11 di SDN Nanggulan menunjukkan bahwa sikap gotong royong yang dimiliki siswa kelas 11 di SDN Nanggulan masih rendah. Hasil persentase jumlah siswa yang memiliki sikap gotong royong dalam kategori 
cukup secara keseluruhan yaitu $45,16 \%$.

Berdasarkan paparan di atas, peneliti tertarik mengadakan penelitian ini dengan judul "Peningkatkan Karakter Gotong Royong di SDN Jemur Wonosari 1 Surabaya Tahun Pelajaran 2019/2020". Tujuan penelitian ini adalah mendeskripsikan (1) bentuk-bentuk perilaku gotong royong yang masih bertahan, (2) strategi guru dalam mempertahankan dan meningkatkan karakter gotong royong siswanya, (3) tema/topik pembelajaran yang menjadi sarana penanaman dan peningkatan karakter gotong royong siswa.

\section{METODE}

Penelitian ini tergolong penelitian kualitatif karena dilakukan dengan mengamati suatu permasalaahan secara sistematis dan tepat mengenai fakta dan objek pada topik tertentu. Penelitian kualitatif adalah penelitian yang bermaksud untuk memahami dan menghasilkan fenomena-fenomena tentang apa subjek dalam penelitian. Jenis penelitian ini adalah pendekatan kualitatif yang bersifat deskriptif. Penelitian deskriptif adalah penelitian yang dilakukan untuk menggambarkan secara sistematis dan nyata mengenai fakta dan sifat populasi tertentu (Lexy, 2016).

Penelitian kualitatif deskriptif memaparkan dalam bentuk kalimat mengenai apa saja yang dialami oleh subjek penelitian, salah satu yang dipaparkan oleh peneliti adalah perilaku. Penelitian ini mendeskripsikan Peningkatkan Karakter Gotong Royong di SDN Jemur Wonosari 1 Surabaya Tahun Pelajaran 2019/2020. Dalam penelitian ini peneliti memilih lokasi penelitian di Jemursari Kota Surabaya. Penelitian ini dilaksanakan di guru kelas 3a, 3b, 4b, 5b, 6a, 6b SDN Jemur Wonosari 1/417 Surabaya.

Menurut Sugiyono (2016), teknik pengumpulan data merupakan langkah utama dalam mencapai responden yang akan diteliti karena tujuan penelitian adalah untuk mendapatkaan data sesuai data yang diperlukan. Pengumpulan data pada penelitian kualitatif ini dilakukan dengan teknik observasi dan wawancara. Teknik observasi ini digunakan untuk memperoleh data secara langsung perilaku gotong royong siswa kelas $3 \mathrm{a}, 3 \mathrm{~b}, 4 \mathrm{~b}, 5 \mathrm{~b}, 6 \mathrm{a}$, $6 \mathrm{~b}$ SDN Jemur Wonosari Surabaya. Teknik wawancara dilakukan oleh peneliti pada guru kelas $3 a, 3 b, 4 b, 5 b$, $6 a, \quad 6 b$ dengan tujuan untuk memperoleh data lapangan yang bersifat umum kemudian mengerucut dan lebih rinci terhadap permasalahan yang ingin ditanyakan sesuai dengan rancangan yang dibuat.

Analisis data dalam penelitian ini dilakukan setelah mendapatkan data dari lapangan. Data dari hasil penelitian selama di lapangan diolah dan dianalisis secara deskriptif kualitatif. Analisis data kualitatif dari hasil penelitian digunakan untuk menjawab bagaimana penerapan karakter gotong royong. Langkah-langkah yang dilakukan dalam analisis data antara lain: (1) reduksi data: proses pemilihan, pemutusan perhatian pada penyederhanaan, dan transformasi data kasar yang diperoleh di lapangan studi, (2) Display data: proses kumpulan informasi tersusun yang memungkinkan untuk melakukan penarikan kesimpulan dan pengabdian tindakan, (3) Verifikasi data: proses permulaan pengumpulan data, periset kuantitatif mencari makna dari setiap gejala yang diperolehnya dari lapangan (Satriawan, 2010). 


\section{HASIL DAN PEMBAHASAN}

Dari hasil wawancara, dijelaskan bahwa hubungan karakter dengan gotong royong sangat erat sekali dimana setelah siswa belajar dalam pendidikan karakter yang kemudian dipraktikan dalam kehidupan misalnya gotong royong. Gotong royong adalah suatu bentuk kerja sama yang dilakukan secara secara bersama-sama baik di lingkungan sekolah, masyarakat dalam mencapai tujuan tertentu. Hasil observasi yang peneliti amati bahwa hubungan karakter dengan peilaku gotong royong masih dikategorikan baik. Namun hanya beberapa anak yang tidak antusias dalam penanaman perilaku gotong royong di sekoah. Misalnya air minum tumpah beberapa teman sedikit tidak memperdulikannya.

\section{Bentuk-Bentuk Perilaku Gotong Royong yang Masih Bertahan}

Pembentukan karakter sangatlan penting diterapkan dengan krisisnya moral suatu bangsa yang kian menghawatirkan. Kegiatan ini bertujuan membangun kepedulian terhadap siswa kepada lingkungan dan penanaman sikap gotong royong sebagai bentuk penanaman karakter di lingkungan sekolah, keluarga, dan masyarakat. Bentuk perilaku gotong royong yang sampai saat ini yang berjalan di sekolah SDN Jemur Wonosari 1/417 surabaya misalnya:

\section{Piket Kelas}

Piket kelas merupakan salah satu kegiatan kerja sama antar siswa dalam membersihkan kelas. Penanaman karakter gotong royong dilakukan setiap hari di kelas agar siswa menanamkan nilai-nilai karakter gotong royong sejak usia dini. Hal itu sesuai dengan hasil wawancara berikut:
"Bentuk-bentuk perilaku gotong royong yang masih bertahan di kelas seperti kerja piket secara bergantian sesuai dengan jadwal yang sudah ditentukan. Dengan adanya kerja piket setiap hari, siswa secara sendiri akan terbentuk sikap gotong royong ( wawancara dengan G3A, G4B, G5B, G6A, G6B pada tanggal 15-21 Mei 2020 pukul 13.00)".

\section{Jumat Bersih}

Jumat bersih merupakan salah satu kegiatan bersih-bersih dan kerja sama yang dilakukan secara bersamasama di lingkungan sekolah. Tujuan dari kegiatan jumat bersih adalah untuk menjaga kebersihan sekolah agar tetap terjaga dan tehindar dari penyakit. Sehingga dalam melakukan aktivitas akan terasa nyaman.

“Kegiatan jum'at bersih yaitu kerja bakti membersihkan lingkungan sekitar sekolah, pembiasaan ini juga dilakukan oleh seluruh siswa yang ada di sekolah, setiap siswa bergatian tugas untuk kosok WC bareng atau kosok toilet, membersihkan kamar mandi bersama-sama secara bergantian sesuai dengan yang lain, membersihkan taman sekolah seperti mengangkat dan mengulurkan pavling berantai. Tujuannya agar siswa mempunyai sikap karakter gotong royong dan sikap sosial yang tinggi kepada lingkungan atau teman sekolah (wawancara dengan G3A, G3B, G4B, G6A, G6B pada tanggal15-21 Mei 2020 pukul 13.00)".

\section{Tugas Kelompok}

Tugas kelompok merupakan tugas gotong royong yang dilakukan secara bersama-sama yang sudah ditentukan sebelumnya. Biasanya masing-masing kelompok dan anggota kelompok mempunyai hak dan kewajiban yang sama. Mengeluarkan pendapat, 
masukan, dan menghargai pendapat satu sama lain.

"Mengerjakan tugas kelompok
merupakan pekerjaan yang
dilakukan secara bersama-sama
untuk memecahkan suatu
permasalahan yang ada,
musyawarah dan diskusi pelajaran di
kelas juga selalu ditanamkam saat
proses pembelajaran berlangsung.
Agar di dalam kelas siswa mampu
bersosial dengan baik (Wawancara
dengan G3A, G3B, G4B, G5B,
G6A, G6B pukul 13.00)".

Hasil penelitian ini sesuai dengan hasil Ratna K. N., (2014) yang menyimpulkan bahwa kegiatan gotong royong yang dilakukan secara bersamasama dapat mencapai tujuan yang sama. Gotong royong merupakan perilaku yang sering dilakukan manusia dalam mencapai tujuan yang sudah disepakati secara musyawarah. Proses pembentukan karakter di sekolah mengacu pada sikap sosial secara individu maupun pembentukannya sendiri yang merupakan salah satu proses awal dalam aspek sosial. Temuan tersebut sejalan dengan temuan Bintari \& Cecep (2016) yang menyimpulkan bahwa tradisi sambatan yang merupakan kebiasaan warga bergotong royong dalam kehidupan sehari-hari bisa melatih dan membentuk karakter peduli terhadap lingkungan. Temuan tersebut sesuai dengan temuan Putri (2020) yang menyimpulkan bahwa segala tugas akan ringan apabila dilakukan secara bersama-sama yang akan menciptakan rasa saling membantu. Semangat gotong royong dalam kegiatan dan kehidupan masyarakat seperti sekolah, dan masyarakat. temuan tersebut sesuai dengan temuan Saputra, Puspa, \& Osa (2019) menyimpulkan bahwa kegiatan rutin yang dilakukan di SDN
Mardiharjo salah satunya adalah penanaman gotong royong. Selain peduli sosial siswa juga saling bekerja sama dalam menyelesaikan suatu pekerjaan seperti piket kelas, dan membersihkan lingkungan sekolah. Temuan tersebut berbeda dengan temuan Irfan (2016) yang menyimpulkan bahwa nilai-nilai karakter gotong diduga kian samar atau menghilang dari kehidupan saat ini disebabkan kencangnya laju globalisasi.

Perilaku gotong royong di lingkungan sekolah sangat penting yang harus ditanamkan sejak usia dini. Karena gotong royong merupakan salah satu karakter yang perlu dikembangkan untuk bekal siswa ketika dewasa nanti. Peran gotong royong saat ini sangat penting dalam menghadapi era globalisasi saat ini. Hal ini perlu ditanamkan sejak anak hingga dewasa baik dirumah, masyarakat, dan sekolah. Perilaku gotong royong merupakan perilaku karakter yang perlu dikembangkan untuk bekal peserta didik hingga dewasa nanti. Di sekolah adalah peran guru dalam melakukan kewajibannya untuk membimbing, mengarahkan, menuntun siswa agar suatu pekerjaan dapat berlangsung dan tidak membutuhkan waktu yang cukup lama. Perilaku gotong royong selalu ditanamkan setiap hari di sekolah. Mengajak siswa di dalam sekolah memang gampanggampang susah. Namun tidak dapat dipungkiri ada beberapa momen siswa sulit dalam mengikuti kegiatan gotong royong. Jika disimpulkan secara keseluruhan, siswa dikategorikan masih mudah melakukan gotong royong.

Dalam melakukan gotong royong ada beberapa siswa yang sulit untuk melakukan kegiatan gotong royong. Sekolah SDN Jemur Wonosari 1/417 Surabaya mengajak siswa yang 
susah bergotong royong dengan beberapa cara sebagai sebagai berikut: memberikan nasihat ringan tentang penting karakter gotong royong, memberikan contoh betapa menyenangkannya menyelesaikan pekerjaan secara gotong royong, meminta bantuan teman dekatnya untuk merayu supaya nyaman melakukan pekerjaan secara gotong royong, memberikan reward berupa makanan kecil atau permen atau ucapan supaya semangat bergotong royong, memberikan punishment jika masih susah bergotong royong. Namun ini biasanya tugas menulis atau membaca. Untuk mengajak siswa yang susah bergotong royong di halaman sekolah misalnya memanggil dan mendekati siswa tersebut dan kemudian ditanya apa penyebabnya. Sehingga guru dapat memberikan memberikan arahan dan cara mengerjakan hal tersebut.

\section{Strategi Guru Dalam Mempertahankan Dan Meningkatkan Karakter Gotong Royong Siswanya}

Di sekolah SDN Jemur Wonosari 1/417 Surabaya beberapa guru menanamkan gotong royong dengan beberapa cara:

\section{Substansi pembelajaran}

Dalam mempertahankan karakter gotong royong siswa masih menggunakan substansi dalam pembelajaran dalam memenuhi standar kompetensi yang ditetapkan sebagai inti, pokok, isi dalam konteks pembelajaran. Misalnya memberikan contoh langsung dikelas dan anak akan lebih memahami dengan adanya teori dan praktek lansung dalam penerapan gotong royong.
"Substansi pembelajaran yang digunakan dalam penerapan perilaku gotong royong pada anak seperti pemberian tugas contoh kepada anak dalam kehidupan sehari-hari, pembagian tugas pemeran, menyiapkan ruangan kelas untuk bermain (wawancara dengan G3A, G3B, G4B, G6A, G6B, pada tanggal 15-21 Mei 2010 pukul 13.00)".

\section{Memberikan penghargaan}

Penghargaan merupakan sesuatu yang diberikan kepada perorangan jika dari mereka melakukan kompetensi dibidang tertentu. Tujuan adanya penghargaan untuk memberikan motivasi kepada siswa agar mereka produktif dalam mengerjakan suatu pekerjaan yang telah dilakukan.

"Penerapan perilaku gotong
royong perlu adanya reward
berupa semangat atau pujian-
pujian, kata-kata pujian dan
penyemangat akan memberikan
dorongan kepada siswa untuk
melakukan penerapan perilaku
gotong royong. Melalui reward
anak akan muda menanamkan
perilaku gotong royong pada usia
dini. Sehingga siswa menjadi
terbiasa melakukan pembiasaan
dalam penanaman sikap gotong
royong (wawancara dengan G6A
pukul 13.00)".

Hasil yang diperoleh sesuai dengan hasil penelitian Kristanto (2016) menyimpulkan bahwa dalam pengamatannya penerapan model collaborative learning di SDN Gembongan kelas VI mata pelajaran PKn dan juga kelas $\mathrm{V}$ untuk pelajaran Matematika, dalam model yang diterapkan siswa dibentuk dalam suatu kelompok untuk mengerjakan tugasnya. Siswa dibimbing oleh guru agar berkolaborasi dengan teman sekolompoknya dalam mengerjakan 
tugas, secara tidak langsung guru memberikan pendidikan karaker pada siswa dalam roses pembelajaran. Model ini mengarahkan siswa untuk bekerja aktif secara bersama-sama dalam proses pembelajaran baik di lingkungan sekolah, keluarga, dan masyarakat. Sehingga model pembelajaran sebagai salah satu cara efektif yang digunakan dalam menanamkan karakter gotong royong pada anak untuk menciptakan siswa yang berkarakter.

Dalam pendapatnya Yasir \& Kurniawan (2018) menyimpulkan bahwa di sekolah dalam hal ini guru mempunyai tugas dalam menanamkan sikap gotong royong kepeserta didik SDIT Aulia Muara Bulian salah satunya melalui peranan guru, dalam menanamkan sikap gotong royong peserta didik dan keteladanan dalam melaksanakan kegiatan di kelas ataupun di luar kelas supaya peserta didik dapat mengaplikasikan dalam kehidupan sehari-hari. Peran guru menjadi fokus utama untuk mewujudkan pendidikan sesuai dengan tujuan pendidikan nasional. Melalui peran guru diharapkan peserta didik mampu mengaplikasikan tanggung jawab dalam kehidupannya kelak.

Hasil yang diperoleh juga terdapat kesamaan dengan Ardianto \& Wijayanti (2016) menyimpulkan bahwa penanaman karakter di sekolah melakukan beberapa strategi (1), pembelajaran berbasis masalah, (2) pembelajaran kooperatif, pembelajaran berbasis proyek, (4) pembelajaran pelayanan, (5) pembelajaran berbasis kerja. Hasil temuan sesuai dengan Puspita (2020) menyimpulkan bahwa nilai kerja sama, siswa akan diberikan penugasan secara kelompok saat pembelajaran tematik. Kerja kelompok dalam pembelajaran tematik merupakan bentuk penanaman karakter gotong royong pada siswa. Hasil yang diperoleh sesuai dengan $\mathrm{M}$ \& Siti (2019) menyimpulkan bahwa strategi yang digunakan dalam proses penanaman karakter gotong royong di MIN 2 Lombok sebagai berikut 1) piket kelas, 2) dipantau secara langsung saat melakukan gotong royong, 3) menambah tempat pembuangan sampah, 3) gotong royong dalam melakukan kegiatan gotong royong.

Melaui penanaman nilai karakter gotong royong pada anak dalam hal kecil bisa melalui program membuat jadwal atau pembiasaan setiap hari. Guru setiap hari harus menyusun jadwal pendidikan karakter atau pembiasaan yang dilakukan oleh siswa. Seperti pembiasaan membantu orang tua di rumah, pembiasaan hidup bersih, ibadah, membersihkan gotong royong dirumah. Awalnya siswa yang belum terbiasa akan merasa susah untuk melakukan pembiasaan. Namun dengan pemberian pengertian dan arahan, siswa akan terbiasa melakukan kegiatan tersebut.

\section{Tema/Topik Pembelajaran Yang Menjadi Sarana Penanaman Dan Peningkatan Karakter Gotong Royong Siswa.}

Untuk tema atau topik penanaman karakter gotong royong dalam pembelajaran terdapat beberapa mata pelajaran yang diterapkan untuk meningkatkan karakter gotong royong di sekolah. Di SDN Jemur Wonosari 1/417 Surabaya terdapat tema atau topik yang digunakan pada saat proses pembelajaran berlangsung pada semua mata pelajaran:

\section{PKn}

PKn merupakan ilmu yang diperoleh dan mengembangkan bagaimana gejala-gejalan sosial yang 
ada. Dalam pembelajaran sekolah dasar pembelajaran penanaman karakter gotong royong dalam pelajaran pkn seperti siswa mendapatkan tugas kelompok mereka kerja sama dalam memecahkan suatu masalah dalam pembelajaran pkn. Melalui pembelajaran tugas kelompok tersebut siswa secara tidak langsung berfikir secara kritis dalam menanggapi isu kewarganegaraan.

\section{Bahasa Indonesia}

Pembelajaran bahasa Indonesia merupakan proses pembelajaran yang wajib dilaksanakan pada pendidikan di Indonesia. Tujuan pendidikan bahasa Indonesia adalah agar siswa dapat menguasai dan memahami bahasa Indonesia dengan baik. Bahasa Indonesia dalam pembelajaran dalam penanaman nilai gotong royong dalam lingkungan sekolah seperti siswa membuat puisi beruntun, membuat cerpen, membuat kesimpulan dari alur cerita yang diberikan oleh guru secara kelompok dan semua kelompok menyampaikan hasil diskusi kedepan kelas.

\section{IPS}

Mata pelajaran IPS merupakan proses mata pelajaran yang diberikan ke sekolah dasar. Tujuan dalam pembelajaran ini adalah agar siswa dapat mengkaji peristiwa-peristiwa apa saja yang terjadi di Indonesia penanaman perilaku gotong royong seperti dalam tugas kelompok mencari kebudayaan yang terjadi dizaman kuno.

\section{Matematika}

\begin{tabular}{lcr}
\multicolumn{2}{c}{ Pembelajaran } & \multicolumn{2}{r}{ matematika } \\
merupakan & proses & \multicolumn{2}{c}{ pembelajaran } \\
kepada siswa & melalui dari & beberapa \\
serangkaian & kegiatan & dalam \\
pembelajaran & matematika. & Proses
\end{tabular}

penanaman perilaku gotong royong pada siswa dalam proses pembelajaran matematika seperti setiap kelompok menyebutkan dan menggambarkan bangun ruang yang diberikan oleh guru.

\section{$S B d P$}

SBdP merupakan proses pembelajaran yang mencakup tentang kesenian, kebudayan, dan keterampilan. Penanaman perilaku gotong royong yang dilakukan dalam pembelajaran SBdP misalnya dalam keterampilan melukis secara berkelompok, menari, musik secara bersama-sama, dan membuat kerajinankerajinan seperti membuat celengan dari bahan bekas yang dilakukan secara bersama-sama.

"Dari hasil yang diperoleh bahwa tema atau topik yang menjadi sarana penanaman dan peningkatan karakter gotong royong semua guru menggunakan semua mata pelajaran (wawancara dengan G3A, G3B, G4B, G5B, G6A, G6B pukul 13.00)".

Pembelajaran tematik merupakan sarana yang dibentuk kurikulum. Pendidikan karakter di sekolah merupakan suatu komponen penanaman nilai-nilai karakter baik dalam kemauan, tindakan, untuk melaksanakan nilai-nilai tersebut sehingga menjadi manusia yang berkepribadian dalam pendidikan karakter. Pendidikan di sekolah, semua komponen harus dilibatkan termasuk komponen-komponen dari pendidikan itu sendiri baik sesama, lingkungan, pengelolaan mata pelajaran atau tema yang akan diterapkan.

Hasil yang di dapat sesuai dengan Utomo (2018) menyimpulkan bahwa nilai karakter diinternalisasikan dalam tiga gunung yaitu (1) transformasi, 
(2)transaksi, (3) transinternalisasi nilai. Proses internalisasi nilai karakter gotong royong dalam pembelajaran IPS melalui mediator keteladanan guru dan pengalaman belajar langsung melalui model pembelajaran, metode pembelajaran, dan bahan ajar. Penanaman perilaku gotong royong direalisasikan dalam kehidupan seharihari di sekolah oleh peserta didik seperti kerja bakti, tolong menolong. Internalisasi gotong royong dalam pembelajaran IPS sangat penting dilakukan untuk membangun modal sosial peserta didik di era globlalisasi saat ini.

Hasil yang didapat sesuai dengan Widodo (2020) menyimpulkan bahwa nilai-nilai budaya yang terkandung dalam ritual perang topat terdiri dari nilai kompromi, nilai religius, nilai historis, nilai kebersamaan dan persamaan derajat, nilai gotong royong, nilai musyawarah dan kekeluargaan, serta nilai toleransi. Nilai-nilai tersebut sejalan dengan materi pada kelas IV dan VI. Topik pembelajaran yang digunakan seperti tema 1 "Indahnya Kebersamaan", tema 7 "Indahnya Keragaman di Negriku" dan tema 8 "Daerah Tempat Tinggalku".

Pembentukan karakter sangatlah penting untuk mencapai tujuan gotong royong yang diterapkan di sekolah. Tujuan penelitian ini agar membangun kepedulian siswa dalam mengerjakan sesuatu baik di dalam kelas maupun di luar kelas dalam menanamkan sikap tanggung jawab pada gotong royong siswa sebagai bentuk penanaman karakter di lingkungan sekolah. Sehingga peningkatan perilaku gotong royong yang ditanamkan pada siswa adalah satu cara pembentukan nilai-nilai karakter gotong royong dalam menciptakan siswa yang berkarakter dalam gotong royong. Menurut
Sardiman (2010), pendidikan karakter merupakan aturan nilai-nilai karakter yang dilakukan atas dasar kemauan sendiri (tidak ada paksaan) baik terhadap lingkungan, keluarga maupun sekolah. Tujuan pendidikan karakter pada dasarnya lebih mengutamakan pertumbuhan perilaku individu yang terdapat dalam lembaga pendidikan misalnya berupa tanggapan individu terhadap sosial, mampu menempatkan diri sesuai dengan kemampuan yang ada dalam dirinya, semakin manjadi manusia yang mempunyai banyak relasi dengan lingkungan luar tanpa harus kehilangan tanggung jawabnya terhadap kebebasan, tetapi juga perkembangan perilaku karakter yang dilakukan dalam kehidupan sehari-hari. tidak dapat diukur melalui pengetahuan maupun keterampilan.

Gotong royong merupakan kegiatan yang dilakukan secara bersama-sama dalam mencapai tujuan bersama. Perilaku gotong royong sering dilakukan manusia dalam mencapai tujuan yang musyawarah dan sudah disepakati. Sikap gotong royong mengarah pada pembentukan karakter masing-masing setiap individu. Proses pembentukan karakter tidaklah mudah, karena pembentukan karakter selalu dikaitkan dengan pendidikan. Menurut Muslich (2011), pendidikan karakter merupakan proses mempelajari budaya ke dalam diri seseorang dan masyarakat sehingga menjadi pribadi yang baik. Menurut Takdir (2014), karakter merupakan hal yang baru, sejak zaman dulu pendidikan karakter sudah ada. Karena zaman dulu esensinya dari karakter bukan dari pengertian-peengertiannya, tapi dalam pengaplikasian juga menjadi salah satu pendidikan karakter.

Karaker yang terbentuk dalam jumat bersih tentunya berperan positif terhadap perkembangan karakter anak 
dalam lingkup sosial. Menurut Anas \& Irwanto (2013), ada beberapa tujuan dalam pembentukan mental terhadap karakter anak (1) menumbuhkan kesadaran yang tinggi pada siswa, (2) memandang diri sendiri beda dengan orang lain dengan semua kesamaan yang ada, (3) adanya sikap tenggang rasa dan saling menghargai satu sama lain, dan (4) membentuk rasional dalam jati diri.

Sikap gotong royong pada diri siswa merupakan karakter yang perlu ditanamkan dan diaplikasikan di lingkungan sekolah. Adanya penanaman sikap gotong royong di lingkungan sekolah dapat menciptakan nilai-nilai positif bagi anak. Tenggang rasa dari sikap gotong royong yang dimiliki pada siswa dapat menanamkan peilaku multikulturalisme di lingkungan sekolah. Sikap multikulturalisme yang dimiliki pada siswa sangat penting bagi siswa sebagai bentuk menjunjung tinggi nilai toleransi. Farida \& Sischa (2010) multikulturalisme merupakan cara untuk mempertahankan kebudayaan dengan menjunjung tinggi sikap toleransi terhadap perbedaan. Sikap tersebut perlu ditanamkan pada pendidikan karakter di sekolah. Salah satunya melalui kegiatan piket kelas, membersihkan lingkungan sekolah, merawat hidroponik dalam bentuk merealisasikan sikap kebudayaan dalam lingkungan sekolah. Dengan adanya kegiatan tersebut diharapkan kebudayaan terwujud dengan peilaku gotong royong yang dilakukan siswa di sekolah.

Melalui gotong royong pembentukan karakter melalui pembiasaan akan menghasilkan bibitbitit yang baik. Proses yang dilakukan disekolah misalnya jumat bersih seperti membersihkan lingkungan kelas, membersihkan lingkungan sekolah, ngosek atau membersihkan toilet, menanam hidroponik dapat terwujud dengaan baik. Pembentukan karakter yang dilakukan hari jumat merupakan pembentukan karakter secara sosial. Gotong royong merupakan kegiatan yang mengacu pada sikap soaial individu maupun dengan sesama. Menurut Ratna K. N., (2014) karakter merupakan subjek sebagian integral dari keluarga, kelompok, dan bangsa yang merujuk dalam sebuah pendidikan karakter. Karakter sendiri merupakan proses perwujudan kesadaran masingmasing individu dalam menuju pendidikan karakter melalui aspek sosial. Pendidikan karakter ditekankan pembentukannya melalui sistem dan aturan yang merujuk pada nilai-nilai yang baik agar terciptanya pembentukkan karakter yang baik pula.

Adanya sikap kebudayaan gotong royong yang dilakukan di sekolah merupakan bentuk individu dalam bersosial. Sekolah merupakan wadah dalam peningkatan pembentukan karakter siswa dalam mencapai tujuannya. Di lingkungan sekolah yang diterapkan bukan hanya teoritik saja. Namun dapat diaplikasikan secara akademik maupun nonakademik. Menurut Rosyada (2014), penerapan multikultur yang dilakukan sekolah data dilakukan dengan cara merancang, merencanakan, dan mengontrol.

Secara garis besar perilaku gotong royong akan tercapai apabila dilakukan dengan melalui pembiasaan. Melalui proses tersebut diharapkan siswa dapat mengaplikasikan perilaku gotong royong yang sudah diterapkan di lingkungan sekolah dengan baik. Karena gotong royong yang tinggi menjadi bentuk nilai karakter yang dimiliki oleh siswa. Selain itu, sikap gotong royong menjadi dasar utama dalam mengurangi sikap idividualis atau apatis. Melalui sikap kepedulian 
yang tinggi akan memberikan dampak positif terhadap diri sendiri, keluarga, masyarakat, lingkungan sekolah, dan bangsa. Sebab karakter bangsa yang baik dilihat dari kepedulian yang tinggi, dan toleransi yang dimiliki setiap masyarakatnya. Sekolah menjadi tempat berprosesnya anak bangsa dalam mengembangkan sikap toleransi yang tinggi. Semoga pembahasan ini bisa terealisasikan dengan baik meskipun melalui kegiatan yang sederhana yaitu pernanaman perilaku gotong royong.

\section{KESIMPULAN}

Bentuk-bentuk perilaku gotong royong yang masih bertahan di SDN Jemur Wonosari 1/417 Surabaya seperti piket kelas, jum'at bersih, kerja kelompok. tujuannya agar dapat mengurangi dampak yang diakibatkan modernisasi.

Strategi yang dilakukan guru dalam penanaman dan peningkatan gotong royong siswa di SDN Jemur Wonosari 1/417 Surabaya melalui substansi pembelajaran, dan pemberian penghargaan. Manfaat dari strategi yang dilakukan adalah untuk memberikan motivasi dalam menerapkan perilaku gotong royong.

Untuk tema atau topik pembelajaran yang yang menjadi sarana penanaman dan peningkatan karakter gotong royong siswa seperti memberikan substansi pembelajaran seperti mata pelajaran PKn, IPS, Matematika, Bahasa Indonesia, dan SBdP.

\section{DAFTAR PUSTAKA}

Anas, S., \& Irwanto, A. 2013. Pendidikan Karakter Berbasis Agama dan Budaya Bangsa. Bandung: CV Pustaka Setia.
Anjarwati, W. 2018. Pudarnya Sikap Gotong Royong di Masa Modern Dtinjau Dari Ir.Soekarno. Jurnal Pendidikan , 4-5.

Ardianto, N., \& Wijayanti, P. M. 2016. Peranan Pendidikan Karakter Dalam Menanamkan Nilai-Nilai Kebhinnekaan. Artikel , 405.

Aviani, R. R. 2020. Pengaruh Modernisasi Terhadap Semangat Nasionalisme Daan Gotong Royong Pada Generasi Muda. Artikel , 4-8.

Bintari, N. P., \& Cecep, D. 2016. Peran Pemuda Sebagai Penerus Tradisi Sambatan Dalam Rangka Pembentukan Karakter Gotong royong. Jurnal Pendidikan Ilmu Sosial , 75.

Danial. 2014. Jejak Kepemimpinan Yang Makin Memudar . Artikel Etnohistori , 1.

Djamari. 2016. Penanaman Sikap Gotong Royong Dalam Kegiatan Ekstrakurikuler Pramuka Di Sdn 3 Kronggen Grobogan. tesis, 2.

Farida, H., \& Sischa, R. 2010. Implementasi Pembelajaran Multikulural di Sekolah Dasar Provinsi Daerah Yogyakarta. Artikel, 1.

Hanafi. 2016, Mei Kamis. tentang gotong royong. Dipetik Juni Minggu, 2020, dari http://majalah1000guru.net/2016 /05/budaya-gotong-royongglobalisasi/: www.majalah1000guru.net

Irfan, M. 2016. Croudfunding Sebagai Pemaknaan Energi Gotong Royong Terbarukan. Jurnal , 30. 
Kemendikbud, T. P. 2017. Mentri Pendidikan dan Kebudayaan Republik Indonesia. Konsep dan Penguatan Pendidikan Karakter , 3 .

Khan, Y. 2010. Pendidikan Karakter Berbasis Potensi Diri. Yogyakarta: Pelangi Publishing.

Khotimah, N. D. 2019. Implementasi Program Penguatan Pendidikan Karakter (PPK) melalui kegiatan 5s Di Sekolah Dasar. Jurnal Ilmian Kependidikan, 30.

Kristanto, B. 2016. Penanaman karakter gotong royong siswa melalui pembelajaran collaborative learning pada siswa sekolah dasar. Jurnal PGSD FIP , 6.

Lexy, M. 2016. Metodologi Penelitian Kualitatif. Bandung: PT Remaja Rosdakarya.

M, S., \& Siti, H. 2019. Strategi Guru Dalam Pembentukan Karakter Peduli Lingkungan Bagi Siswa. Jurnal Penelitian Keislaman , 58-63.

Muslich, M. 2011. Pendidikan Karakter Menjawab Tantangan Krisis Multi Deminsional. Jakarta: Bumi Aksara.

Nunzairina. 2018. Implementasi Pendidikan Karakter Dalam Upaya Sekolah di SD IT ALHijrah 2 Laut Dendang. skripsi, 1.

Puspita, C. R. 2020. Internalisasi Nilainilai Karakter Gotong Royong Dalam Pembelajaran Tematik di Kelas 2 SD Tarbiyatul Islam Kertosari Ponorogo. Skripsi , 50.

Putri, S. A. 2020, 02 Kamis. 1. Dipetik Juni minggu, 2020, dari http://www.kompas.com/skola/r ead/2020//02/20/110000769/sem angat-kekeluargaan-dan-gotongroyong-dalam-berbagaikehidupan: www.kompas.com

Ratna, K. N. 2014. Peranan Karya Sastra, Seni Dan Budaya Dalam Pendidikan Karakter. Yogyakarta: Pustaka Pelajar.

Rosyada, D. 2014. Pendidikan Multikulturalisme di Indonesia. Artikel , 1.

Saputra, N. D., Puspa, D., \& Osa, J. 2019. Penanaman Nilai-Nilai Karakter Dalam Budaya Sekolah Berbasis Budaya Lokal di SDN Mardiharjo Kabupaten Musi rawas . Jurnal Pembelajaran dan Pengajaran Pendidikan Dasar, 6.

Sardiman. 2010, Agustus Senin. 1. Dipetik Juni Senin, 2020, dari http://www.uny.ac.id/berita/pen didikan-karakter-mengajarkannilai-nilai-keutamaan-dan-nilainilai-keindonesiaan: http://www.uny.ac.id

Satriawan, A. H. 2010. Penerapan Gaya Mengajar Guru Dengan Memanfaatkan Media Visual Untuk Meningkatkan Keaktifan Siswa Dalam Pembelajaran Teori Pemesinan Siswa Kelas Xi Kompetensi Keahlian Teknik Pemesinan Smk Bhineka Karya Surakarta Tahun Pelajaran 2009/2010. Skripsi , 28-29.

Setiawan, D. O. 2016. Peningkatan Karakter Gotong Royong Melalui Pelaksanaan Pembelajaran PKn Dengan Model Cooperative Lerning Tipe Jigsaw Untuk Siswa Kelas Ii Di SDN Nanggulan. Skripsi, 3. 
Sugiyono. 2016. Metode Penelitian Pendekatan Kuantitatif, Kualitatif, dan $R \& D$. Bandung: Alfabeta.

Takdir, M. 2014. Pendidikan Yang Mencerahkan. Malang: UMM Press.

Utomo, P. E. (2018). Internalisasi Nilai Karakter Gotong Royong Dalam Pembelajaran IPS Untuk Membangun Modal Sosial Peserta Didik. Jurnal Teori dan Praksis Pembelajaran IPS , 1.

Widodo, A. 2020. Nilai Budaya Ritual Perang Topat Sebagai Sumber Pembelajaran IPS Berbasis Kearifan Lokal di Sekolah Dasar. Jurnal Studi Sosial , 213.

Yasir, A., \& Kurniawan, R. A. (2018). Peran Guru Dalam Menumbuhkan Sikap Gotong Royong Bagi Siswa dI Sekolah Dasar. Artikel , 5. 